\title{
Paradoxal effect of atropine: are we doing our best to prevent it?
}

\author{
Alves, DR ${ }^{1}$; Amim, $\mathrm{S}^{2}$; Gonçalves, $\mathrm{N}^{2}$ ('Anaesthesiology resident; ${ }^{2}$ Anaesthesiology Fellow) \\ Centro Hospitalar de Lisboa Ocidental, Lisbon, Portugal; Head of Department: Manuel Chedas
}

Background and Goal of Study: Atropine was isolated over 180 years ago ${ }^{1}$, but some peculiarities of its action are still surrounded by doubt. Small doses of the drug have been found to cause a paradoxal effect ${ }^{2}$, but international resuscitation guidelines uphold the use of $0,5 \mathrm{mg}$ as an initial dose for adults, regardless of body weight ${ }^{3}$. In daily practice, however, different clinicians prefer to use $10 \mathrm{mcg} / \mathrm{Kg}$. We decided to see if there was any difference in the incidence of paradoxal effect of atropine with either option, auditing local practice throughout an year.

Materials and Methods: Retrospective study (audit) comparing data from patients treated with either $0,5 \mathrm{mg}$ or $10 \mathrm{mcg} / \mathrm{kg}$ iv atropine intraoperatively due to severe bradicardia (HR< $40 \mathrm{bpm}$ ) accompanied by hypotension.

Results and Discussion: We identified 16 such patients in the study period. Of these, 12 had received $0,5 \mathrm{mg}$ of atropine irrespective of body weight, 7 of whom $(58,3 \%)$ developed a paradoxal effect, manifest as a junctional rhythm that promptly reverted with administration of a further $0,5 \mathrm{mg}$ iv atropine.

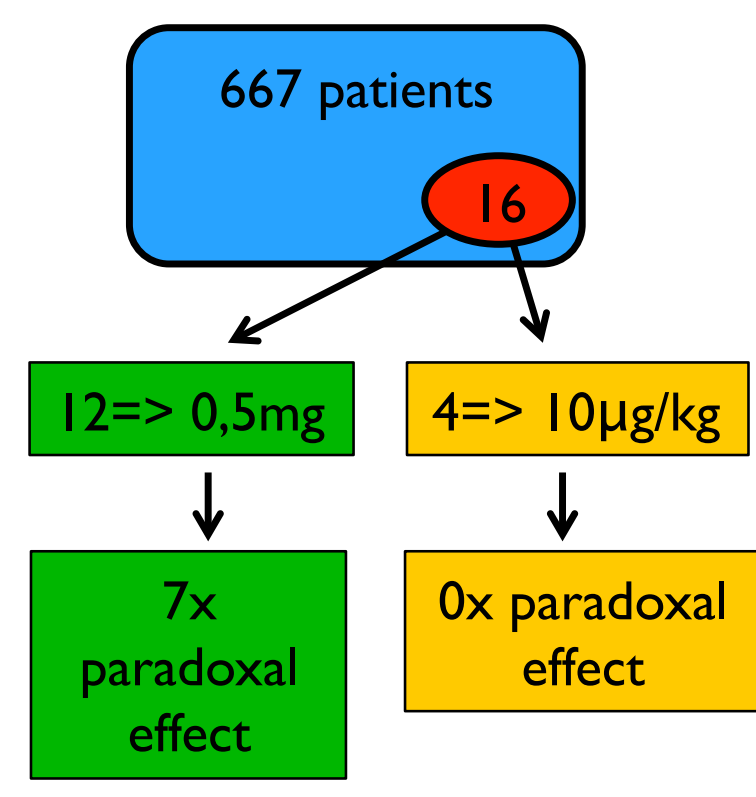

Figure I - Subgroups in the study sample.

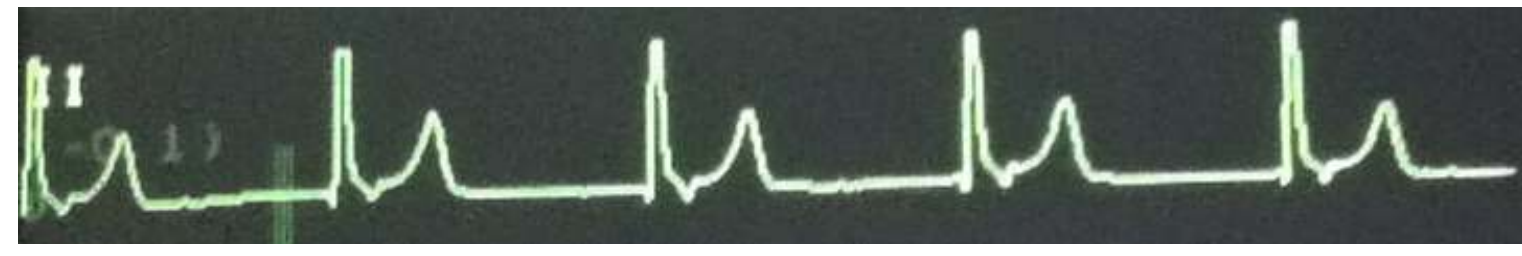

Figure 2 - Junctional rhythm after administration of $0,5 \mathrm{mg}$ atropine, with characteristic retrograde atrial depolarization waves, negative in $D_{\| 1}$.

Most of these patients (5 out of 7 ) were also receiving remifentanil which, interestingly, was administered to only 1 of the 5 patients treated with the same dose $(0,5 \mathrm{mg})$ of atropine but that did not develop paradoxal effect.

4 individuals were treated with $10 \mathrm{mcg} / \mathrm{Kg}$ of atropine, none of which developed a paradoxal effect, even though 3 were concurrently receiving remifentanil.

The small number of patients involved does not allow us to find statistically significant differences in the dose of atropine administered (indexed to body weight) between those who did and those who did not experience a paradoxal effect (p-value for both Fisher's exact test and Mann-Whitney test $>0,05$ ), which would be important to support its role in the etiopathogenesis of this complication. However, logistic regression with the outcome variable defined as development of a paradoxal effect and independent variables being atropine dose and remifentanil use does lead to a statistically significant model (Omnibus test $p$-value $=0,012$ ), adjusted to the data (HosmerLemeshow test $p$-value $=1,0$ ), with a Nagelkerke pseudo- $R^{2}$ of 0,571 , even though individual Wald statistics show a $p$-value $>0,05$. Once again, such is likely due to the small sample size, which disadvises the use of a logistic regression model for this analysis.

\begin{tabular}{|c|c|c|c|c|c|}
\hline & AGE & SEX & DOSE & $\begin{array}{l}\text { ANAES- } \\
\text { THESIA }\end{array}$ & $\begin{array}{l}\text { SYSTEMIC } \\
\text { OPIOID }\end{array}$ \\
\hline $\begin{array}{c}0,5 \mathrm{mg} \text { atr. }+ \\
\text { pdx effect }\end{array}$ & $52 \pm 12$ & 4F:3M & $6,8 \pm 1,3$ & $\begin{array}{l}6 \times B G A \\
\text { IxSAB }\end{array}$ & $\begin{array}{c}\text { |xFentanyl } \\
\text { 5xRemifentany| }\end{array}$ \\
\hline $\begin{array}{c}0,5 \mathrm{mg} \text { atr., } \\
\text { no pdx effect }\end{array}$ & $60 \pm 19$ & $2 F: 3 M$ & $6,6 \pm 1,6$ & $\begin{array}{l}4 \times B G A \\
I \times S A B\end{array}$ & $\begin{array}{c}\text { 3xFentanyl } \\
\text { |xRemifentanyl }\end{array}$ \\
\hline $\begin{array}{l}10 \mu \mathrm{g} / \mathrm{kg} \text { atr., } \\
\text { no pdx effect }\end{array}$ & $74 \pm 12$ & IF:3M & 10 & $4 \times B G A$ & $\begin{array}{c}\text { |xFentanyl } \\
\text { 3xRemifentanyl }\end{array}$ \\
\hline
\end{tabular}

Table I - Characteristics of patients in different groups.

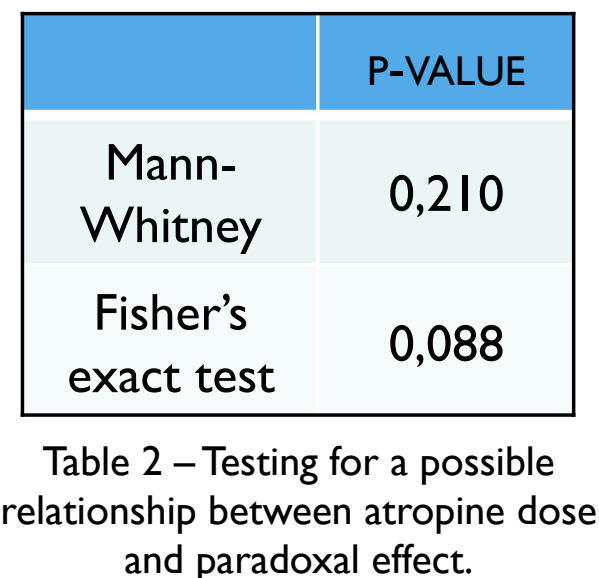
and paradoxal effect.

\begin{tabular}{|c|c|c|}
\hline $\begin{array}{c}\text { Omnibus } \\
\text { test } \\
\text { Hosmer- }\end{array}$ & P-VALUE & STATISTIC \\
$\begin{array}{c}\text { Lemeshow } \\
\text { Nagelkerke } \\
\mathrm{R}^{2}\end{array}$ & $\mathrm{I}, 000$ & \\
$\begin{array}{c}\text { Wald } \\
\text { atr. Dose } \\
\text { Wald }_{\text {opioid }}\end{array}$ & 0,999 & $0,57 \mathrm{I}$ \\
\hline \multicolumn{2}{|c|}{ Table 3 - Logistic regression model $^{\text {characteristics. }}$} \\
\hline
\end{tabular}

Pharmacodynamic explanation for the paradoxal effect of atropine: Atropine is a competitive antagonist of muscarinic acetylcholine receptors. Low concentrations of the drug are thought to bind preferentially to $M_{1}$ receptor subtypes, which are presynaptic and have an important role in limiting the amount of acetylcholine released into the synaptic cleft ${ }^{4}$. Antagonism of this mechanism predisposes to acumulation of the neurotransmitter and thus exacerbates vagotonia - leading to a paradoxal effect. Larger concentrations of atropine readily antagonise $M_{2}$ and $M_{3}$ subtypes (postsynaptic), overriding this mechanism, i.e., preventing the existing acetylcholine from binding to muscarinic receptors on the effector cells.

Conclusions: The present study suggests that the paradoxal effect of atropine may be more common than usually considered, being found in day-to-day anaesthesiologic practice. The intraoperative period may be particularly suitable for this occurrence, considering the state of increased vagotonia consequent to anaesthesia.

We suggest that a small dose of atropine $(0,5 \mathrm{mg}$ in large patients), especially when remifentanil is also being used, may constitute a particularly risky combination, but acknowledge that further, larger studies are needed to properly clarify the matter.

\section{References:}

1. Brown JH, Taylor P. Chapter 7 - Muscarinic receptor agonists and antagonists. In: Hardman JG, Limbird LE, Gilman AG, editors. Goodman \& Gilman's The Pharmacological basis of therapeutics, I0th ed. New York: McGraw-Hill; 200I. p. I55-I73.

2. Bettermann H, Cysarz D, Portsteffen A, Kümmell HC. Bimodal dose-dependent effect on autonomic, cardiac control after oral administration of Atropa belladona. Auton Neurosci. 2001;196:1-10.

3. Soar J, Nolan JP, Böttiger BW et al. European Resuscitation Council Guidelines for Resuscitation 2015: Section 3. Adult advanced life support. Resuscitation. 2015;95:100-147.

4. Barrington K. The myth of a minimum dose for atropine. Pediatrics. 201 I;127(783): 783-784;. 6. Tirel $O$ et al. Effect of remifentanil with and without atropine on heart rate variability and RR interval in children. Anaesthesia. 2005;60:982-989. 